\title{
Response of benthic organisms to seasonal change of organic matter deposition in the bathyal Sagami Bay, central Japan
}

\author{
Motohiro SHIMANAGA ${ }^{a *}$, Yoshihisa SHIRAYAMA ${ }^{\text {b }}$ \\ a Ocean Research Institute, University of Tokyo, 1-15-1, Minami-dai, Nakano, Tokyo 164, Japan \\ b Seto Marine Biological Laboratory, Graduate School of Science, Kyoto University, Shirahama-cho, \\ Wakayama 649-2211, Japan.
}

Received 6 June 1999; revised 30 August 1999; accepted 1 October 1999

\begin{abstract}
An interdisciplinary research project was carried out to understand seasonal carbon cycling in a deep-sea ecosystem in Sagami Bay, central Japan. Temporal changes in the chloroplastic pigment (CPE) concentration in the sediment, as well as the abundance, the biomass and the metabolic activity of benthic organisms were studied. CPE was detectable throughout the year, and its amount increased in the spring when a fluffy layer was observed on the surface of the sediment. Significant seasonal fluctuation of bacterial abundance was found, but the range was small, the maximal value being only 1.6 times larger than the minimal one. Metabolic activity did not show significant temporal difference. The abundance and biomass of metazoan meiofauna seemed to fluctuate seasonally, but ANOVA did not confirm it statistically. Our results suggest that if enough organic matter is supplied constantly, the deep-sea benthic community will be stable even though seasonality of organic matter flux associated with the spring bloom exists. C 2000 Ifremer/CNRS/IRD/Éditions scientifiques et médicales Elsevier SAS
\end{abstract}

seasonal change / meiobenthic abundance / bacterial abundance / metabolic activity / chloroplastic pigment concentration

Résumé - Réponse des organismes benthiques aux variations saisonnières de la matière organique déposée dans la baie de Sagami, au centre du Japon. Un programme de recherche interdisciplinaire a été consacré au cycle saisonnier du carbone dans un écosystème profond de la baie de Sagami, au centre du Japon. Les variations temporelles de la concentration du pigment chloroplastique (CPE) dans le sédiment ont été étudiées, ainsi que l'abondance, la biomasse et l'activité métabolique des organismes benthiques. La concentration CPE est détectable pendant toute l'année, avec une augmentation au printemps lorsqu'une couche pelucheuse est observée à la surface du sédiment. L'abondance bactérienne présente une fluctuation saisonnière significative mais de faible amplitude, avec un rapport de 1,6 entre les valeurs maximale et minimale. L'activité métabolique ne varie pas de manière significative avec le temps. L'abondance et la biomasse de la méiofaune de métazoaires semblent fluctuer avec les saisons, sans confirmation statistique Anova. Les résultats montrent que la communauté benthique profonde reste stable si l'apport de matière organique est suffisant et continu, même avec une variabilité saisonnière associée à la floraison printanière. C 2000 Ifremer/CNRS/IRD/Éditions scientifiques et médicales Elsevier SAS

variation printanière / abondance méiobenthique / abondance bactérienne / activité métabolique / concentration en pigment chloroplastique

\footnotetext{
* Correspondence and reprints: motohiro@ori.u-tokyo.ac.jp
} 


\section{INTRODUCTION}

The deep-sea floor below water depths of $1000 \mathrm{~m}$ has been perceived as a remote and stable environment, because in the region, the deep water column attenuates and buffers the flux of energy and organic nutrient from the surface. According to this view, the ecological tempo of deep-sea life has been considered to be very slow [42].

In the 1980s, sediment trap studies provided the first indications of fast transport of particulate organic matter (POM) and seasonal fluctuations in its intensity $[9,24,46]$. The first direct evidence for the mass sedimentation of phytodetrital matter to the sea bed came from photographic observations [27, 39] and sediment sampling [6] in the Porcupine Seabight, NE Atlantic. Similar phenomena were found in the northwest Atlantic slope [21], the abyssal equatorial Pacific (see [42]) and the abyssal NE Pacific [5].

Phytodetrital accumulations were studied also at the BIOTRANS site [47], one of the most intensively investigated benthic stations in the open northeast Atlantic [14, 15, 17, 28, 29, 33, 34, 37, 40, 49, 50]. At this site, Pfannkuche [34] used chlorophyll $a$ concentrations in the sediment as an indicator of the sedimentation of phytodetritus, and found that sedimentation occurred in late April-early May, and reached a maximum in June-July. The smaller-sized groups of the benthic community consisting of mainly bacteria and protozoa reacted to the event by increasing their abundance and biomass.

Along the ocean margin, eutrophic deep-sea environments can be found. Although the environments form a significant pool of carbon at global level [51], only a few studies have been done regarding the ecological coupling between surface water and the deep sea in the area (e.g. $[8,35])$.

To address this issue, an interdisciplinary research project, named 'Project Sagami', has been carried out in the central part of Sagami Bay, Japan, since 1996. Previous studies at this site have shown that the number of living individuals of benthic foraminifers changed seasonally $[25,31]$. This research focused on monitoring the seasonal change of organic carbon flux from the sea surface to the bottom. For this purpose, primary production, the sinking flux of organic matter, the depositional behaviour of organic matter in the benthic boundary layer, and population dynamics of the benthic biota were studied [26].

This report focuses on observations of four parameters, i.e., 1) the concentration of chloroplastic pigment equivalents (CPE) in the sediment, as an indicator of the amount of sedimented phytoplankton; 2) bacterial abundance; 3) the adenylate energy charge (EC) as a measurement of the metabolic condition of organisms in the sediment; 4) the abundance, biomass and median size of metazoan meiobenthos in the sediment. The temporal fluctuation patterns of these parameters are compared in order to address the seasonality of the benthic community in the eutrophic deep-sea site.

\section{MATERIAL AND METHODS}

\subsection{The study area and sampling dates}

A fixed sampling station, St. SB, was established at a bathyal depth in the central part of Sagami Bay $\left(35^{\circ} 00^{\prime} \mathrm{N}, 139^{\circ} 22.5^{\prime} \mathrm{E}, 1430 \mathrm{~m}\right.$ depth; figure 1$)$. We sampled 15 times between December 1996 and August 1998 at an average interval of 1.4 months using R.V. Tansei-maru of the Ocean Research Institute, University of Tokyo or Rinkai-maru of Misaki Marine Biological Station, University of Tokyo (table I).

\subsection{Sampling}

Sampling was conducted using multiple corers (MC) [4], that had already proved suitable for the collection of phytodetritus [6, 39, 47]. Subsamples for studies of chloroplastic pigments, bacterial abundances and total adenylates were taken from a core using cut-off syringes sterilized in advance. Three replicates were taken for each parameter, except when the sample was partially disturbed (sample numbers of each parameter were shown in table I). For studies of chloroplastic pigments and bacterial number, the glass syringes (cross-section $0.71 \mathrm{~cm}^{2}$ ) were used to subsample down to a depth of $9 \mathrm{~cm}$. For the study of total adenylates, plastic syringes were used to subsample to a depth of $5 \mathrm{~cm}$. On board the ship, these samples were sectioned horizontally into 1-cm-thick 
layers down to the depth of $5 \mathrm{~cm}$, and deeper than that depth, they were sliced into 2 -cm-thick layers.

For analyses of meiofauna, sediments in other cores were used. In cases where there was fluffy phytodetritus on the sediment, it was collected from sediment separately using a pipette.

\subsection{Chloroplastic pigment equivalents}

As an indication of the amount of sedimented phytoplankton, we measured the distribution of chloroplastic pigment equivalents (CPE: chlorophyll $a+$ pheopigments) in the upper $9 \mathrm{~cm}$ of sediment. Sedi- ment samples collected in sterile glass sub-cores were sliced as described above, and stored at $-20^{\circ} \mathrm{C}$ for further processing in the laboratory. For extraction of pigments, $7.1 \mathrm{~mL}$ of $90 \%$ acetone was added per $0.71 \mathrm{~cm}^{3}$ of wet sediment in a plastic tube and homogenized using a test tube mixer for $30 \mathrm{~s}$. For more complete pigment extraction, samples in sealed tubes were stored overnight in the dark under $4{ }^{\circ} \mathrm{C}$. After centrifugation for $30 \mathrm{~min}$ at $3500 \mathrm{rpm}$, the concentration of CPE in the supernatant was measured using a Turner fluorometer following the method described by Yentsch and Menzel [52] and Holm-Hansen et al. [23]. All processes were done within three weeks of sampling.

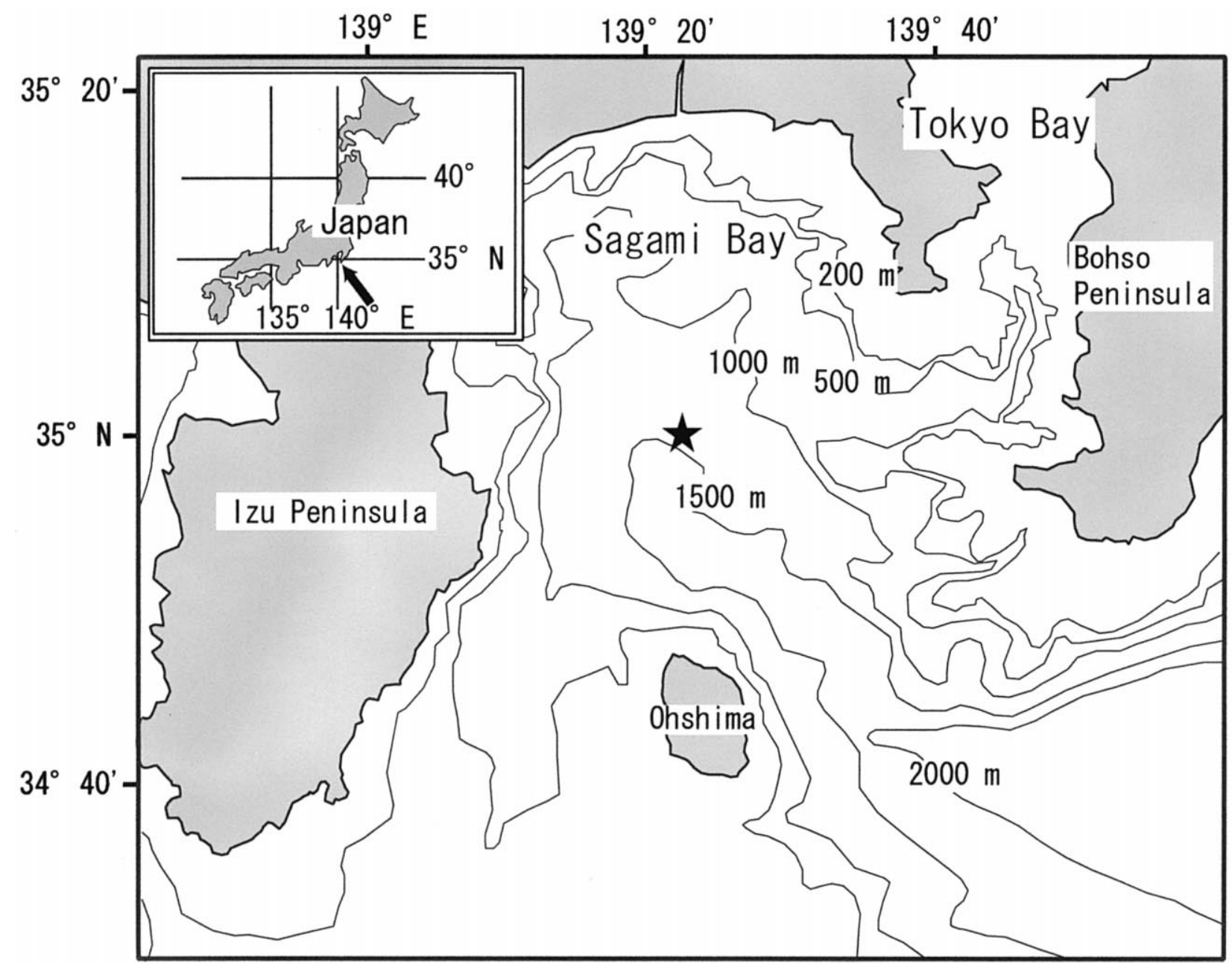

Figure 1. Location of study site in Sagami Bay, central Japan. 
Table I. List of sampling dates, sampling stations, and numbers of samples taken for different purposes ${ }^{\mathrm{a}}$

\begin{tabular}{|c|c|c|c|c|c|c|c|c|}
\hline Cruise & Date & Latitude & Longitude & Depth & $\mathrm{CPE}$ & Bacteria & $\mathrm{EC}$ & Meiofauna \\
\hline KT-96-20 & $\begin{array}{l}\text { 10th Dec. } 1996 \\
\text { 11th Dec. } 1996 \\
\text { 11th Dec. } 1996\end{array}$ & $\begin{array}{l}35^{\circ} 00.1 \mathrm{~N} \\
35^{\circ} 00.0 \mathrm{~N} \\
34^{\circ} 59.9 \mathrm{~N}\end{array}$ & $\begin{array}{l}139^{\circ} 20.9 \mathrm{E} \\
139^{\circ} 22.3 \mathrm{E} \\
139^{\circ} 22.2 \mathrm{E}\end{array}$ & $\begin{array}{l}1459 \mathrm{~m} \\
1439 \mathrm{~m} \\
1580 \mathrm{~m}\end{array}$ & $\begin{array}{l}5 \\
1 \\
2\end{array}$ & $\begin{array}{l}6 \\
3 \\
3\end{array}$ & $\begin{array}{l}4 \\
2 \\
1\end{array}$ & $\begin{array}{l}1 \\
1 \\
1\end{array}$ \\
\hline KT-97-1 & $\begin{array}{l}\text { 24th Feb. } 1997 \\
\text { 26th Feb. } 1997 \\
\text { 26th Feb. } 1997 \\
\text { 26th Feb. } 1997\end{array}$ & $\begin{array}{l}35^{\circ} 00.6 \mathrm{~N} \\
35^{\circ} 00.2 \mathrm{~N} \\
35^{\circ} 00.9 \mathrm{~N} \\
35^{\circ} 00.3 \mathrm{~N}\end{array}$ & $\begin{array}{l}139^{\circ} 22.9 \mathrm{E} \\
139^{\circ} 22.5 \mathrm{E} \\
139^{\circ} 22.8 \mathrm{E} \\
139^{\circ} 22.8 \mathrm{E}\end{array}$ & $\begin{array}{l}1412 \mathrm{~m} \\
1426 \mathrm{~m} \\
1409 \mathrm{~m} \\
1468 \mathrm{~m}\end{array}$ & $\begin{array}{l}3 \\
2 \\
3\end{array}$ & $\begin{array}{l}3 \\
3 \\
2\end{array}$ & $\begin{array}{l}1 \\
1 \\
1\end{array}$ & $\begin{array}{l}1 \\
1 \\
1\end{array}$ \\
\hline TR-97-1 & 2nd Apr. 1997 & $35^{\circ} 00.0 \mathrm{~N}$ & $139^{\circ} 22.9 \mathrm{E}$ & $1405 \mathrm{~m}$ & 3 & 3 & 3 & 1 \\
\hline TR-97-2 & $\begin{array}{l}\text { 12th May } 1997 \\
\text { 13th May } 1997\end{array}$ & $\begin{array}{l}35^{\circ} 00.0 \mathrm{~N} \\
35^{\circ} 00.7 \mathrm{~N}\end{array}$ & $\begin{array}{l}139^{\circ} 23.1 \mathrm{E} \\
139^{\circ} 23.1 \mathrm{E}\end{array}$ & $\begin{array}{l}1400 \mathrm{~m} \\
1400 \mathrm{~m}\end{array}$ & 3 & 3 & 3 & 1 \\
\hline KT-97-7 & $\begin{array}{l}\text { 4th Jun. } 1997 \\
\text { 4th Jun. } 1997\end{array}$ & $\begin{array}{l}35^{\circ} 00.1 \mathrm{~N} \\
34^{\circ} 59.9 \mathrm{~N}\end{array}$ & $\begin{array}{l}139^{\circ} 22.7 \mathrm{E} \\
139^{\circ} 22.9 \mathrm{E}\end{array}$ & $\begin{array}{l}1419 \mathrm{~m} \\
1421 \mathrm{~m}\end{array}$ & $\begin{array}{l}2 \\
2\end{array}$ & $\begin{array}{l}2 \\
2\end{array}$ & $\begin{array}{l}2 \\
2\end{array}$ & $\begin{array}{l}1 \\
1\end{array}$ \\
\hline KT-97-9 & $\begin{array}{l}\text { 22nd Jun. } 1997 \\
\text { 24th Jun. } 1997\end{array}$ & $\begin{array}{l}35^{\circ} 00.0 \mathrm{~N} \\
35^{\circ} 00.1 \mathrm{~N}\end{array}$ & $\begin{array}{l}139^{\circ} 21.9 \mathrm{E} \\
139^{\circ} 22.3 \mathrm{E}\end{array}$ & $\begin{array}{l}1460 \mathrm{~m} \\
1437 \mathrm{~m}\end{array}$ & $\begin{array}{l}3 \\
3\end{array}$ & $\begin{array}{l}3 \\
3\end{array}$ & $\begin{array}{l}3 \\
2\end{array}$ & $\begin{array}{l}1 \\
1\end{array}$ \\
\hline TR-97-3 & $\begin{array}{l}\text { 21st Aug. } 1997 \\
\text { 22nd Aug. } 1997\end{array}$ & $\begin{array}{l}35^{\circ} 00.6 \mathrm{~N} \\
35^{\circ} 00.5 \mathrm{~N}\end{array}$ & $\begin{array}{l}139^{\circ} 23.6 \mathrm{E} \\
139^{\circ} 23.2 \mathrm{E}\end{array}$ & $\begin{array}{l}?^{\mathrm{b}} \\
?\end{array}$ & 3 & 3 & & 1 \\
\hline TR-97-4 & $\begin{array}{l}\text { 2nd Oct. } 1997 \\
\text { 2nd Oct. } 1997\end{array}$ & $\begin{array}{l}35^{\circ} 00.2 \mathrm{~N} \\
35^{\circ} 00.2 \mathrm{~N}\end{array}$ & $\begin{array}{l}139^{\circ} 22.3 \mathrm{E} \\
139^{\circ} 22.2 \mathrm{E}\end{array}$ & $\begin{array}{l}? \\
1450 \mathrm{~m}\end{array}$ & 3 & 3 & 3 & 1 \\
\hline TR-97-5 & $\begin{array}{l}\text { 6th Nov. } 1997 \\
\text { 6th Nov. } 1997\end{array}$ & $\begin{array}{l}34^{\circ} 59.8 \mathrm{~N} \\
34^{\circ} 59.8 \mathrm{~N}\end{array}$ & $\begin{array}{l}139^{\circ} 22.6 \mathrm{E} \\
139^{\circ} 22.7 \mathrm{E}\end{array}$ & $\begin{array}{l}1420 \mathrm{~m} \\
1420 \mathrm{~m}\end{array}$ & 3 & 3 & 3 & 1 \\
\hline KT-97-19 & $\begin{array}{l}\text { 11th Dec. } 1997 \\
\text { 11th Dec. } 1997 \\
\text { 12th Dec. } 1997 \\
\text { 13th Dec. } 1997\end{array}$ & $\begin{array}{l}35^{\circ} 00.6 \mathrm{~N} \\
34^{\circ} 59.8 \mathrm{~N} \\
35^{\circ} 00.0 \mathrm{~N} \\
35^{\circ} 00.3 \mathrm{~N}\end{array}$ & $\begin{array}{l}139^{\circ} 22.2 \mathrm{E} \\
139^{\circ} 22.7 \mathrm{E} \\
139^{\circ} 22.4 \mathrm{E} \\
139^{\circ} 22.6 \mathrm{E}\end{array}$ & $\begin{array}{l}1435 \mathrm{~m} \\
1435 \mathrm{~m} \\
1432 \mathrm{~m} \\
1422 \mathrm{~m}\end{array}$ & $\begin{array}{l}3 \\
3 \\
3\end{array}$ & $\begin{array}{l}3 \\
2 \\
3\end{array}$ & $\begin{array}{l}2 \\
1 \\
1\end{array}$ & $\begin{array}{l}1 \\
1 \\
1\end{array}$ \\
\hline TR-98-1 & $\begin{array}{l}\text { 27th Feb. } 1998 \\
\text { 27th Feb. } 1998\end{array}$ & $\begin{array}{l}35^{\circ} 00.0 \mathrm{~N} \\
35^{\circ} 00.0 \mathrm{~N}\end{array}$ & $\begin{array}{l}139^{\circ} 22.4 \mathrm{E} \\
139^{\circ} 22.2 \mathrm{E}\end{array}$ & $\begin{array}{l}1425 \mathrm{~m} \\
1425 \mathrm{~m}\end{array}$ & 3 & 3 & 3 & 1 \\
\hline KT-98-3 & 14th Mar. 1998 & $34^{\circ} 59.9 \mathrm{~N}$ & $139^{\circ} 22.5 \mathrm{E}$ & $1431 \mathrm{~m}$ & 3 & 3 & 3 & 1 \\
\hline TR-98-2 & $\begin{array}{l}\text { 16th Apr. } 1998 \\
\text { 16th Apr. } 1998\end{array}$ & $\begin{array}{l}35^{\circ} 00.0 \mathrm{~N} \\
35^{\circ} 00.1 \mathrm{~N}\end{array}$ & $\begin{array}{l}139^{\circ} 22.8 \mathrm{E} \\
139^{\circ} 22.9 \mathrm{E}\end{array}$ & $\begin{array}{l}1410 \mathrm{~m} \\
1400 \mathrm{~m}\end{array}$ & 3 & 3 & 3 & 1 \\
\hline KT-98-7 & $\begin{array}{l}\text { 21st May } 1998 \\
\text { 21st May } 1998 \\
\text { 22nd May } 1998\end{array}$ & $\begin{array}{l}35^{\circ} 00.6 \mathrm{~N} \\
35^{\circ} 00.4 \mathrm{~N} \\
35^{\circ} 00.6 \mathrm{~N}\end{array}$ & $\begin{array}{l}139^{\circ} 22.2 \mathrm{E} \\
139^{\circ} 22.7 \mathrm{E} \\
139^{\circ} 22.4 \mathrm{E}\end{array}$ & $\begin{array}{l}1441 \mathrm{~m} \\
1419 \mathrm{~m} \\
1439 \mathrm{~m}\end{array}$ & $\begin{array}{l}3 \\
3 \\
3\end{array}$ & $\begin{array}{l}3 \\
3 \\
3\end{array}$ & $\begin{array}{l}2 \\
2 \\
2\end{array}$ & $\begin{array}{l}1 \\
1 \\
1\end{array}$ \\
\hline KT-98-14 & $\begin{array}{l}\text { 26th Aug. } 1998 \\
\text { 26th Aug. } 1998 \\
\text { 27th Aug. } 1998\end{array}$ & $\begin{array}{l}35^{\circ} 00.2 \mathrm{~N} \\
35^{\circ} 00.1 \mathrm{~N} \\
34^{\circ} 58.5 \mathrm{~N}\end{array}$ & $\begin{array}{l}139^{\circ} 22.9 \mathrm{E} \\
139^{\circ} 22.9 \mathrm{E} \\
139^{\circ} 22.9 \mathrm{E}\end{array}$ & $\begin{array}{l}1416 \mathrm{~m} \\
1416 \mathrm{~m} \\
1418 \mathrm{~m}\end{array}$ & $\begin{array}{l}3 \\
3 \\
3\end{array}$ & $\begin{array}{l}3 \\
3 \\
3\end{array}$ & $\begin{array}{l}3 \\
3\end{array}$ & $\begin{array}{l}1 \\
1 \\
1\end{array}$ \\
\hline
\end{tabular}

${ }^{a}$ KT-, TR- denote a cruise of R/V Tansei Maru, and Rinkai Maru, respectively.

${ }^{\mathrm{b}}$ Echo sounder did not work.

\subsection{Bacterial number}

Sliced samples were fixed and preserved in $9 \mathrm{~mL}$ of $4 \%$ formalin in buffered, filtered $(0.22 \mu \mathrm{m})$, and autoclaved seawater and stored at $4{ }^{\circ} \mathrm{C}$ in the dark until further processing in the laboratory. Before determining total bacterial number, samples were homogenized for $1 \mathrm{~min}$ and sonicated for $1 \mathrm{~min}$. Then these samples were diluted by approximately 1000 fold with particle-free DDW. Bacterial numbers were determined by staining cells with $4^{\prime}$ 6-diamidino-2phenylindole (DAPI) and directly counted using an 
epifluorescence microscopy as described by Porter and Feig [38]. Counting was carried out on at least twenty fields for each sample. All processes were done within three weeks of sample collection.

\subsection{Adenylate Energy Charge}

The adenylate energy charge (EC) was chosen as a measure of the metabolic condition of organisms in the sediment. The adenylate energy charge represents the energy available for metabolism in a living cell [1]. It is calculated from the amounts of three adenylate nucleotides by the equation:

$$
\mathrm{EC}=(\mathrm{ATP}+1 / 2 \mathrm{ADP}) /(\mathrm{ATP}+\mathrm{ADP}+\mathrm{AMP})[2,7]
$$

Under conditions favourable for growth and active metabolism, the ratio is close to 1 , i.e. all the adenylates are in the form of ATP. In this study, the sediment for analysis of total adenylates was sampled using a syringe with the end cut off. The syringe and sediment were immediately frozen using liquid $\mathrm{N}_{2}$ and stored at $-20^{\circ} \mathrm{C}$ on board the ship. Immediately after each cruise, the sediment was sliced at $1-\mathrm{cm}$ intervals and immersed in glycinebuffer to extract the total adenylates (ATP + ADP + AMP). Total adenylates were measured following the procedure described by Greiser and Faubel [20].

\subsection{Meiofauna}

Cores for analyzing meiofauna were sliced horizontally into $0-0.25,0.25-0.5,0.5-0.75,0.75-1,1-2$, $2-3,3-4$, and $4-5-\mathrm{cm}$ layers to study their vertical distribution. The sliced sediment samples were fixed immediately and preserved separately in 5\% neutralized seawater formalin. Rose Bengal $\left(0.5 \mathrm{~g} \cdot \mathrm{L}^{-1}\right)$ was added to this solution to stain the samples. In the laboratory, the fixed sediments were wet-sieved using six mesh sizes: $1.0,0.5,0.25,0.125,0.063$, and 0.031 $\mathrm{mm}$. The samples retained were transferred into flatbottomed petri dishes, and the organisms stained by Rose Bengal were sorted, classified and counted under a binocular stereoscopic microscope. Meiofaunal numbers were converted into the biomass (AFDW) using the method of Shirayama [41]. The value of 0.4 was used to calculate carbon weight from AFDW (see [11]). Median sizes of meiofauna were calculated as $50 \%$ intercept of the cumulative curves of meiobenthic weight against mesh size (phi unit, i.e. $\left.-\log _{2} \mathrm{~mm}\right)$ [41].

\subsection{Analysis of data}

For each parameter, we investigated differences between months by one-way ANOVA (at $\alpha=0.05$ level). Prior to the analysis of variance, all data were transformed by $\log _{10}(x+1)$ to reduce the heterogeneity and the assumption of homogeneity of variances was checked using Bartlett's test. Because this test revealed heterogeneity of variances for CPE amount and bacterial numbers $(P<0.05)$, we gave up using parametric test for these parameters, and non-parametric one i.e. the KruskalWallis test was used to test the presence of seasonal variation of each parameter [53]. For analyses of meiofauna, we used only seven data that have replicates (see table I). For those taxa that were found only from the surface layer of the sediment, data from subsurface $(>2 \mathrm{~cm})$ layers were disregarded. In cases where significant differences were detected by ANOVA, multiple comparisons of density estimates were carried out by the SNK test [53].

\section{RESULTS}

\subsection{CPE in the sediment}

Chloroplastic pigment equivalents (CPE) were detectable in the top 9-cm layer of the sediment throughout the study period. Concentrations did not decrease drastically with depth in the sediment (figure 2). However, in May 1997, April and May 1998, the CPE amount was high especially in the top $2 \mathrm{~cm}$ of the sediment. Below $2 \mathrm{~cm}, \mathrm{CPE}$ value was constant throughout the year. The Kruskal-Wallis tests demonstrated that significant temporal changes of the CPE amount existed in all sediment layers down to $9 \mathrm{~cm}$ depth, and the sum of the top $5 \mathrm{~cm}$ of sediment (figure 2). The mean ( \pm standard deviation) of the integrated CPE amount within the top $5 \mathrm{~cm}$ of sediment was $79 \pm 13 \mu \mathrm{g} \cdot \mathrm{cm}^{-2}$ during the study period (table II). 


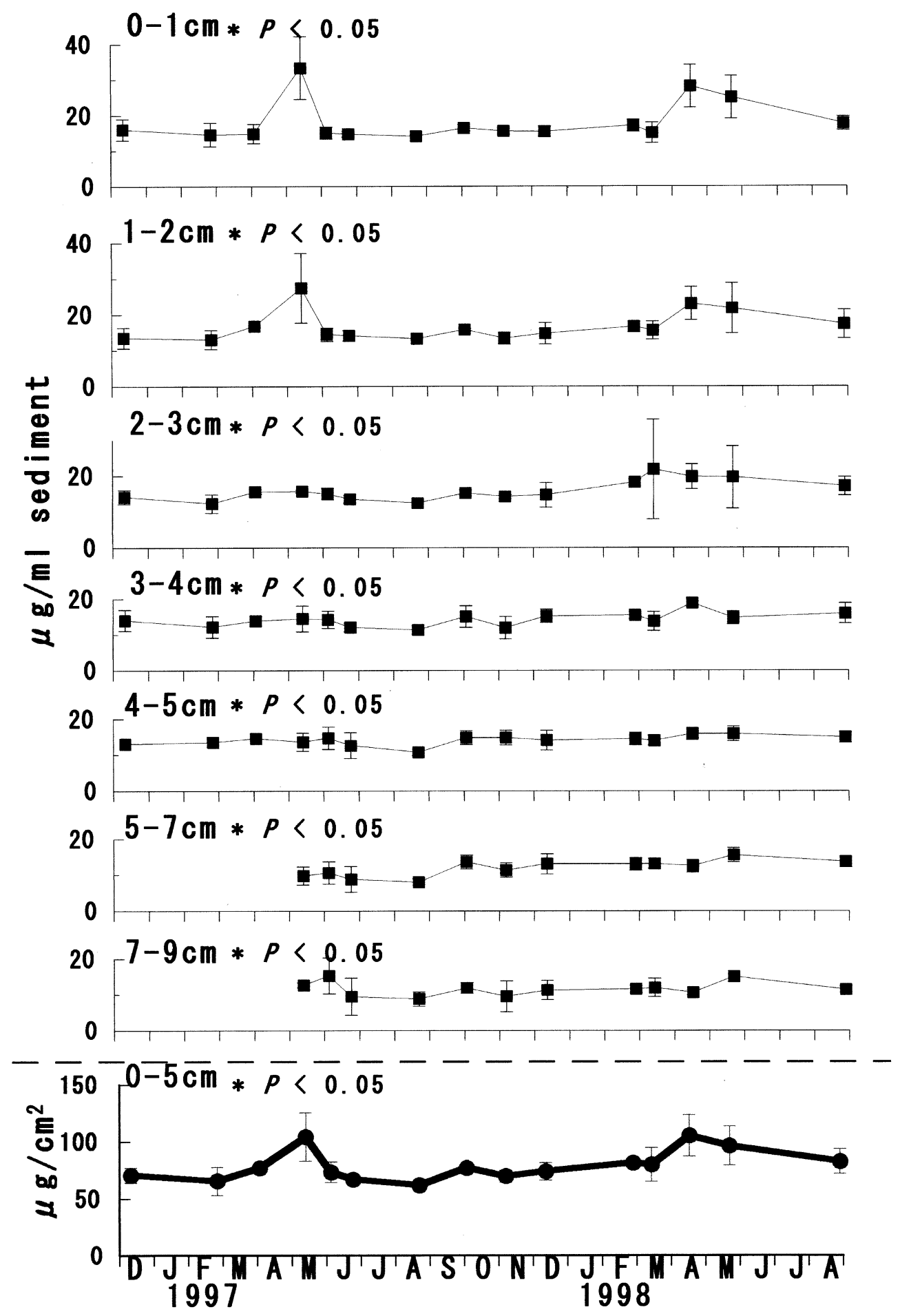

Figure 2. Seasonal change of CPE concentration in the sediment. Dots, and bars denote the average, the standard deviation, respectively. ${ }^{*} P<0.05$ denotes that the Kruskal-Wallis test detected significant difference. 


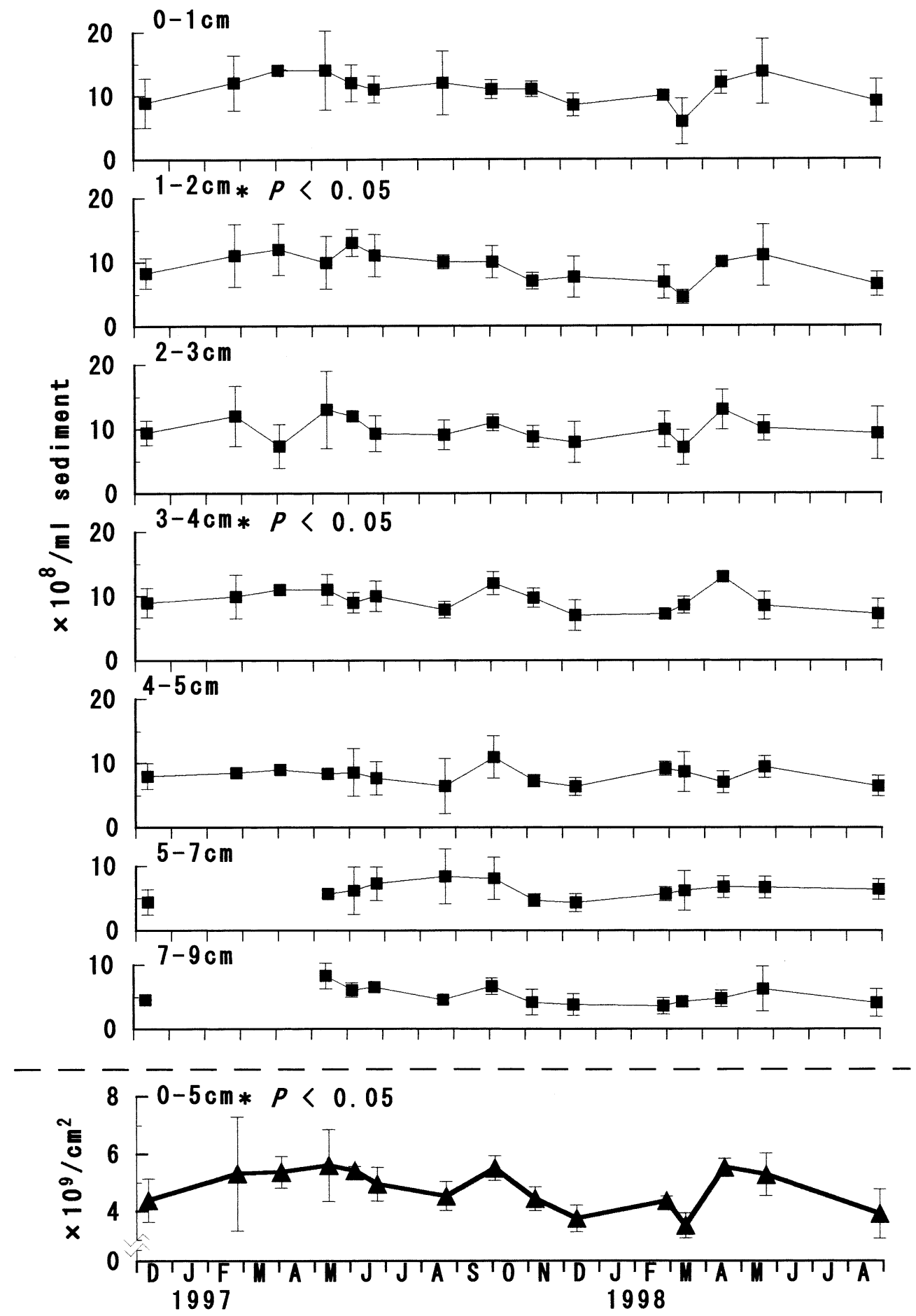

Figure 3. Seasonal change of bacterial abundance in the sediment. Dots, and bars denote the average, the standard deviation, respectively. ${ }^{*} P<0.05$ denotes that the Kruskal-Wallis test detected significant difference. 


\subsection{Bacterial numbers}

The density of bacteria decreased with depth into the sediment (figure 3). This trend, however, was not so distinct that the number of bacteria in the 7-9 $\mathrm{cm}$ layer of the sediment was usually about a half of the figure in the topmost $1 \mathrm{~cm}$ layer. The abundance of bacteria in the sediment tended to decrease in the winter. For this parameter, again, Kruskal-Wallis tests detected significant temporal changes in the 1-2 $\mathrm{cm}$ and $3-4 \mathrm{~cm}$ layer of the sediment as well as the integrated value of the top 5-cm layer.

\subsection{EC}

The EC values did not show distinct temporal or vertical changes and stayed at a low level (about 0.5) at this site throughout the study period (figure 4). Because the Bartlett's test confirmed the homogeneity of variances among EC data, we applied one-way ANOVA $(\alpha=0.05)$ to the data. However, it did not detect significant difference in any layer of sediment.

\subsection{Seasonal change in the abundance, biomass and median size of meiofauna}

The abundance of meiofauna decreased with depth in the sediment throughout all seasons. The trend was more drastic than in the case of bacteria (figure 5), namely about $50 \%$ of total meiofauna distributed within the top $1 \mathrm{~cm}$ of sediment throughout the years. The average and standard deviation of total metazoan meiofauna within the top $5 \mathrm{~cm}$ of sediment was $1044 \pm 362$ individuals $/ 10 \mathrm{~cm}^{2}$ during the study period (table II). Nematodes were always the most abundant metazoan taxon throughout the year accounting for $65 \%$ of all metazoan meiofauna on average. Copepods $(14 \%)$ and Nauplii $(13 \%)$ were also abundant. Polychaeta $(2.4 \%)$, Kinorhyncha $(1.4 \%)$, and Ostracoda (1.3\%) also were found frequently. These six meiofaunal groups comprised $97 \%$ of whole metazoan meiofauna in the present study (table III). The abundance of these meiofaunal groups decreased with depth in the sediment throughout the years. In the case of nematodes, this trend was weaker than those of the other groups.

Table II. Chemical composition, bacterial numbers, activities and meiofaunal abundance/biomass in sediment samples ${ }^{\mathrm{a}}$

\begin{tabular}{|c|c|c|c|c|c|c|c|c|c|c|}
\hline \multirow[t]{2}{*}{ Year } & \multirow[t]{2}{*}{ Month } & \multicolumn{2}{|l|}{$\begin{array}{l}\mathrm{CPE} \\
\left(\mu \mathrm{g} / \mathrm{cm}^{2}\right)\end{array}$} & \multicolumn{2}{|c|}{$\begin{array}{l}\text { Bacterial number } \\
\left(\times 10^{9} \text { cells } / \mathrm{cm}^{2}\right)\end{array}$} & \multirow[t]{2}{*}{$\mathrm{EC}(0-5 \mathrm{~cm})$} & \multicolumn{2}{|c|}{$\begin{array}{l}\text { Metazan meiofauna }(0-5 \mathrm{~cm}) \\
\text { Abundance }\left(\text { ind. } / 10 \mathrm{~cm}^{2}\right)\end{array}$} & \multicolumn{2}{|l|}{ Biomass $\left(\mathrm{gC} / \mathrm{m}^{2}\right)$} \\
\hline & & $0-5 \mathrm{~cm}$ & $5-9 \mathrm{~cm}$ & $0-5 \mathrm{~cm}$ & $5-9 \mathrm{~cm}$ & & $(0.03-0.5 \mathrm{~mm})$ & $(0.5-1.0 \mathrm{~mm})$ & $(0.03-0.5 \mathrm{~mm})$ & $(0.5-1.0 \mathrm{~mm})$ \\
\hline 1996 & December & 71 & n.d. ${ }^{\mathrm{b}}$ & 4.4 & 1.8 & 0.47 & 809 & 1 & 0.18 & 0.06 \\
\hline \multirow[t]{9}{*}{1997} & February & 66 & n.d.? & 5.3 & n.d.? & 0.35 & 942 & 7 & 0.17 & 0.05 \\
\hline & April & 77 & n.d.? & 5.4 & n.d.? & 0.49 & 1636 & 14 & 0.21 & 0.13 \\
\hline & May & 104 & 45 & 5.6 & 2.8 & 0.35 & 1633 & 11 & 0.28 & 0.08 \\
\hline & June1 & 73 & 52 & 5.4 & 2.5 & 0.35 & 848 & 7 & 0.15 & 0.06 \\
\hline & June2 & 67 & 37 & 5.0 & 2.8 & 0.40 & 1442 & 9 & 0.30 & 0.08 \\
\hline & August & 62 & 34 & 4.5 & 2.6 & n.d.? & 1073 & 2 & 0.12 & 0.02 \\
\hline & October & 77 & 51 & 5.5 & 3.0 & 0.49 & 849 & 3 & 0.16 & 0.04 \\
\hline & November & 70 & 42 & 4.4 & 1.8 & 0.40 & 502 & 4 & 0.11 & 0.06 \\
\hline & December & 74 & 49 & 3.7 & 1.6 & 0.51 & 889 & 4 & 0.19 & 0.05 \\
\hline \multirow[t]{6}{*}{1998} & February & 82 & 49 & 4.4 & 1.9 & 0.47 & 636 & 1 & 0.15 & 0.02 \\
\hline & March & 80 & 50 & 3.5 & 2.1 & 0.51 & 871 & 5 & 0.20 & 0.09 \\
\hline & April & 106 & 46 & 5.5 & 2.3 & 0.46 & 1534 & 5 & 0.26 & 0.07 \\
\hline & May & 97 & 61 & 5.3 & 2.6 & 0.33 & 1087 & 2 & 0.17 & 0.02 \\
\hline & August & 83 & 50 & 3.9 & 2.1 & 0.37 & 826 & 4 & 0.20 & 0.06 \\
\hline & Average $^{\mathrm{c}}$ & 79 & 47 & 4.8 & 2.3 & 0.42 & 1038 & 5.3 & 0.19 & 0.06 \\
\hline
\end{tabular}

${ }^{\text {a }}$ Each values denote aveage of samples for each parameter $0-5 \mathrm{~cm}, 5-9 \mathrm{~cm}$ denote samples integrated from 0 to $5 \mathrm{~cm}, 5$ to $9 \mathrm{~cm}$, respectively.

${ }^{\mathrm{b}}$ Not determined.

${ }^{c}$ Average values throughout the sampling period $(\mathrm{N}=15)$. 

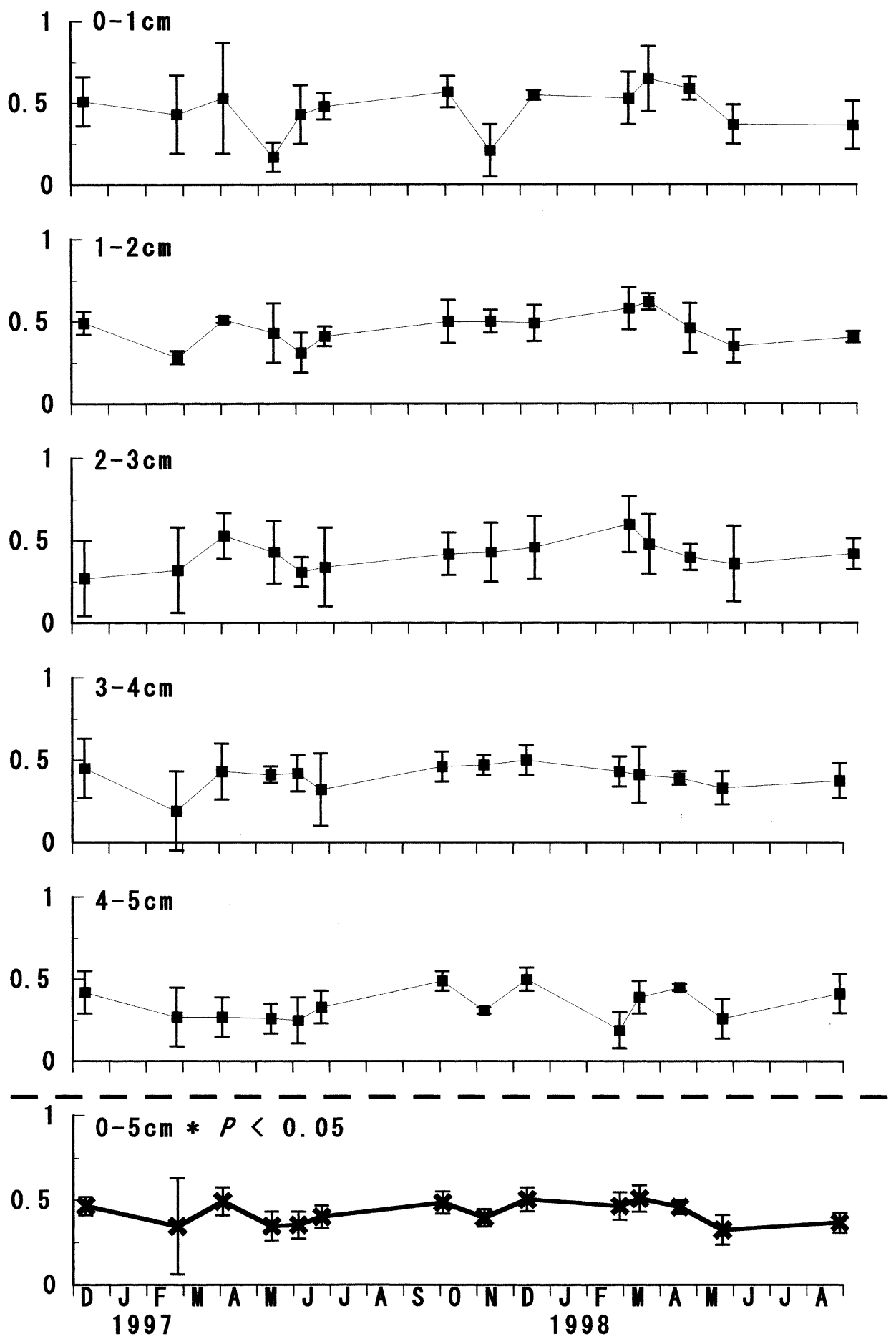

Figure 4. Seasonal change of EC in the sediment. Dots and bars denote the average and the standard deviation, respectively. 

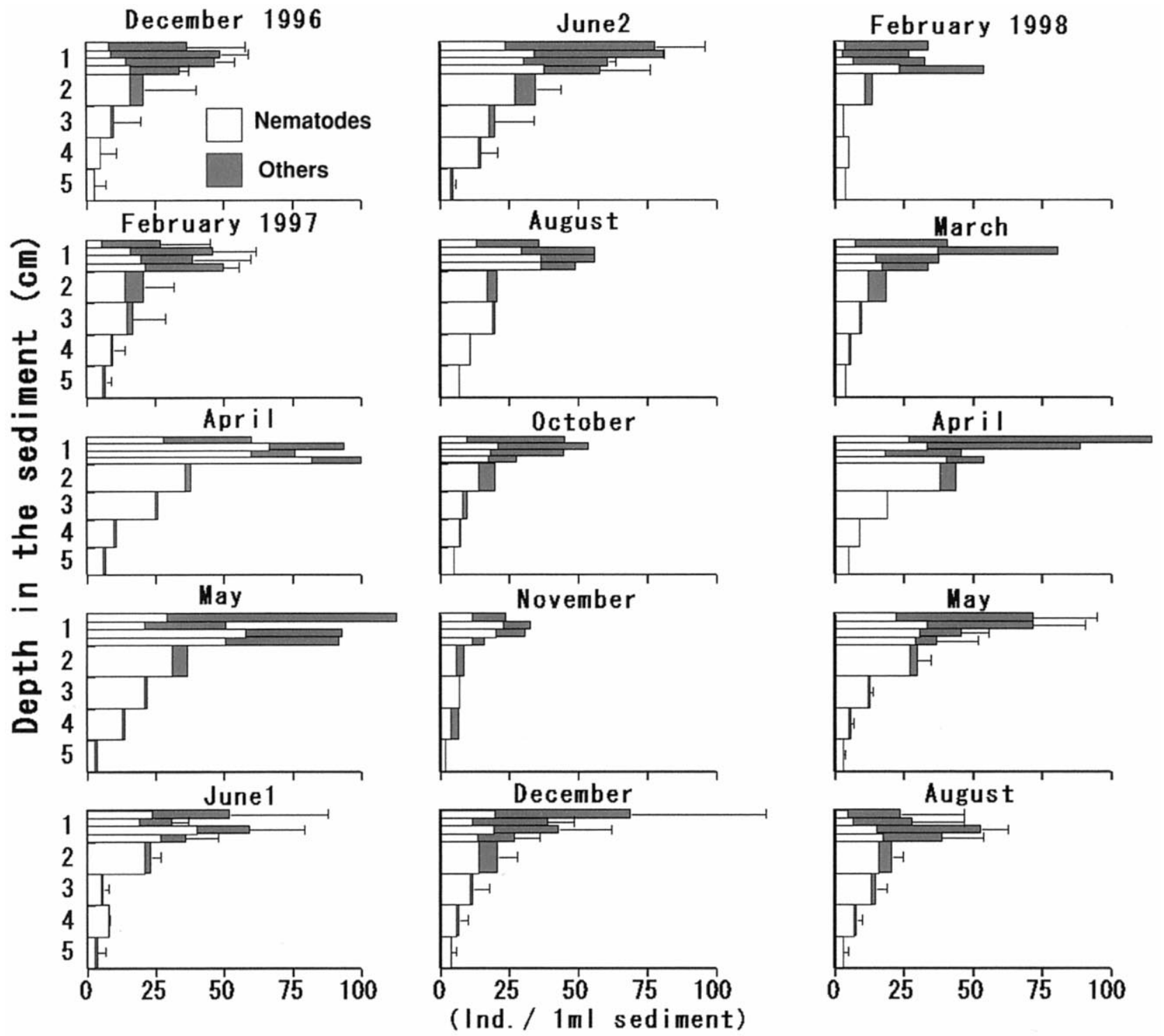

Figure 5. Vertical distribution of total meiofauna and nematodes in the sediment. Bars denote the standard deviation of total meiofauna.

Consequently, below $2 \mathrm{~cm}$ depth in the sediment as much as $85 \%$ of total meiofaunal individuals were occupied by nematodes throughout all seasons (figure 5).

The density of total meiofauna and nematodes within the top $5 \mathrm{~cm}$ of the sediment showed weak seasonal fluctuation in both 1997 and 1998. The peaks of abundance of these parameters synchronized with the periods when CPE concentration increased in the sediment (figure 6). One-way ANOVA, however, did not confirm the presence of temporal fluctuation for these parameters.

The mean abundance of copepods (adults plus copepodites) fluctuated from season to season, but the pattern did not seem to be seasonal (figure 6). Oneway ANOVA did not detect significant temporal change of abundance for this group of animals. The results were the same for the abundance of polychaetes, kinorhynchs and ostracodes (table IV). 
For the numbers of nauplii, on the other hand, significant difference could be detected by one-way ANOVA in the density of $0.25-0.50 \mathrm{~cm}$ and $0.75-1.0$ $\mathrm{cm}$ layers, and integrated number of individuals within the top $5 \mathrm{~cm}$ of the sediment (table $I V$ ). The SNK test, however, led to an ambiguous interpretation that integrated numbers in late June 1997 and December 1996 were larger than those in early June 1997 (table V). The results for biomass were basically the same as for the abundance.

Median size of total meiofauna and nematodes were constant throughout the years (figure 7). For copepods, on the other hand, multiple comparisons detected significant difference in the median size between May 1998 and early 1997 (table V).

\section{DISCUSSION}

\subsection{Food supply to the deep-sea floor}

There was significant temporal change in the amount of CPE in the sediment at our study site. The concentration was maximum in spring (April or May) in both years. When the concentration of CPE was high, the fluffy layer was found on the surface of the sediment. However, CPE was detectable in the sediment throughout the year though chloroplastic pigments are known to decay for some ten days in oxic sediments [35]. These observations suggest that the supply of organic matter to our site is continuous, though it increases in the spring. A sediment trap set $350 \mathrm{~m}$ above the bottom and near the sampling site $\left(34^{\circ} 58.5 \mathrm{~N}, 139^{\circ} 20.9 \mathrm{E}\right.$, depth $\left.1544 \mathrm{~m}\right)$, collected particulate organic matter constantly, and detected the increase of CPE concentration in the particles from March to April in both 1997 and 1998 (Nakatsuka, pers. comm.). This observation coincides with the pattern of CPE concentrations in the sediment, suggesting that organic matter sinking at $1200 \mathrm{~m}$ depth reaches the sea floor $(1450 \mathrm{~m})$ in a short time.

Noriki et al. [30] showed that lithogenic particles are transported from the mouth of Tokyo Bay to the open ocean (see figure 1). Their data suggest that lateral advection of organic matter through the horizontal transport should also be important at our site. Due to this constant horizontal supply, the fluctuation of vertical organic matter flux to our study site was not distinct enough to show a sharp peak in CPE values of the sediment. A similar weak increase of chlorophyll $a$ concentration also was observed in the eastern North Pacific [43].

Table III. Temporal change of mean number per $10 \mathrm{~cm}^{2}$ and standard deviation of major meiofaunal taxa/groups within the top $5 \mathrm{~cm}$ of sediment

\begin{tabular}{|c|c|c|c|c|c|c|c|c|}
\hline & & Nematodes & Copepods & Nauplii & Polychaetes & Kinorhynchs & Ostracods & Others \\
\hline 1996 & December & $443 \pm 74$ & $144 \pm 32$ & $153 \pm 28$ & $23 \pm 6$ & $9 \pm 5$ & $15 \pm 3$ & $25 \pm 23$ \\
\hline \multirow[t]{9}{*}{1997} & February & $599 \pm 289$ & $146 \pm 7$ & $123 \pm 44$ & $20 \pm 9$ & $10 \pm 6$ & $20 \pm 7$ & $31 \pm 21$ \\
\hline & April & 1359 & $112^{-}$ & 102 & $15^{-}$ & $11^{-}$ & 6 & $46^{-}$ \\
\hline & May & 1067 & 177 & 186 & 31 & 31 & 13 & 139 \\
\hline & June1 & $651 \pm 48$ & $94 \pm 32$ & $71 \pm 1$ & $18 \pm 4$ & $9 \pm 7$ & $7 \pm 2$ & $5 \pm 0$ \\
\hline & June2 & $945 \pm 305$ & $194 \pm 3$ & $200 \pm 24$ & $30 \pm 7$ & $22 \pm 4$ & $17 \pm 2$ & $42 \pm 11$ \\
\hline & August & $829^{-}$ & $68^{-}$ & 131 & 22 & $4^{-}$ & $6^{-}$ & $16^{-}$ \\
\hline & October & 504 & 139 & 146 & 26 & 17 & 9 & 10 \\
\hline & November & 357 & 59 & 59 & 12 & 11 & 3 & 5 \\
\hline & December & $510 \pm 233$ & $173 \pm 50$ & $134 \pm 26$ & $23 \pm 7$ & $21 \pm 12$ & $20 \pm 13$ & $13 \pm 14$ \\
\hline \multirow[t]{6}{*}{1998} & February & 316 & 158 & 100 & 27 & 7 & 12 & 16 \\
\hline & March & 496 & 176 & 122 & 26 & 16 & 11 & 30 \\
\hline & April & 1006 & 160 & 238 & 18 & 32 & 22 & 64 \\
\hline & May & $767 \pm 161$ & $120 \pm 19$ & $129 \pm 28$ & $23 \pm 7$ & $18 \pm 5$ & $17 \pm 2$ & $14 \pm 6$ \\
\hline & August & $489 \pm 68$ & $163 \pm 60$ & $108 \pm 26$ & $23 \pm 6$ & $8 \pm 7$ & $11 \pm 6$ & $27 \pm 18$ \\
\hline & Average $^{\mathrm{a}}$ & $689 \pm 298$ & $139 \pm 41$ & $134 \pm 47$ & $23 \pm 5$ & $15 \pm 8.4$ & $13 \pm 5.7$ & $32 \pm 34$ \\
\hline
\end{tabular}

\footnotetext{
average values throughout the sampling period $(\mathrm{N}=15)$.
} 


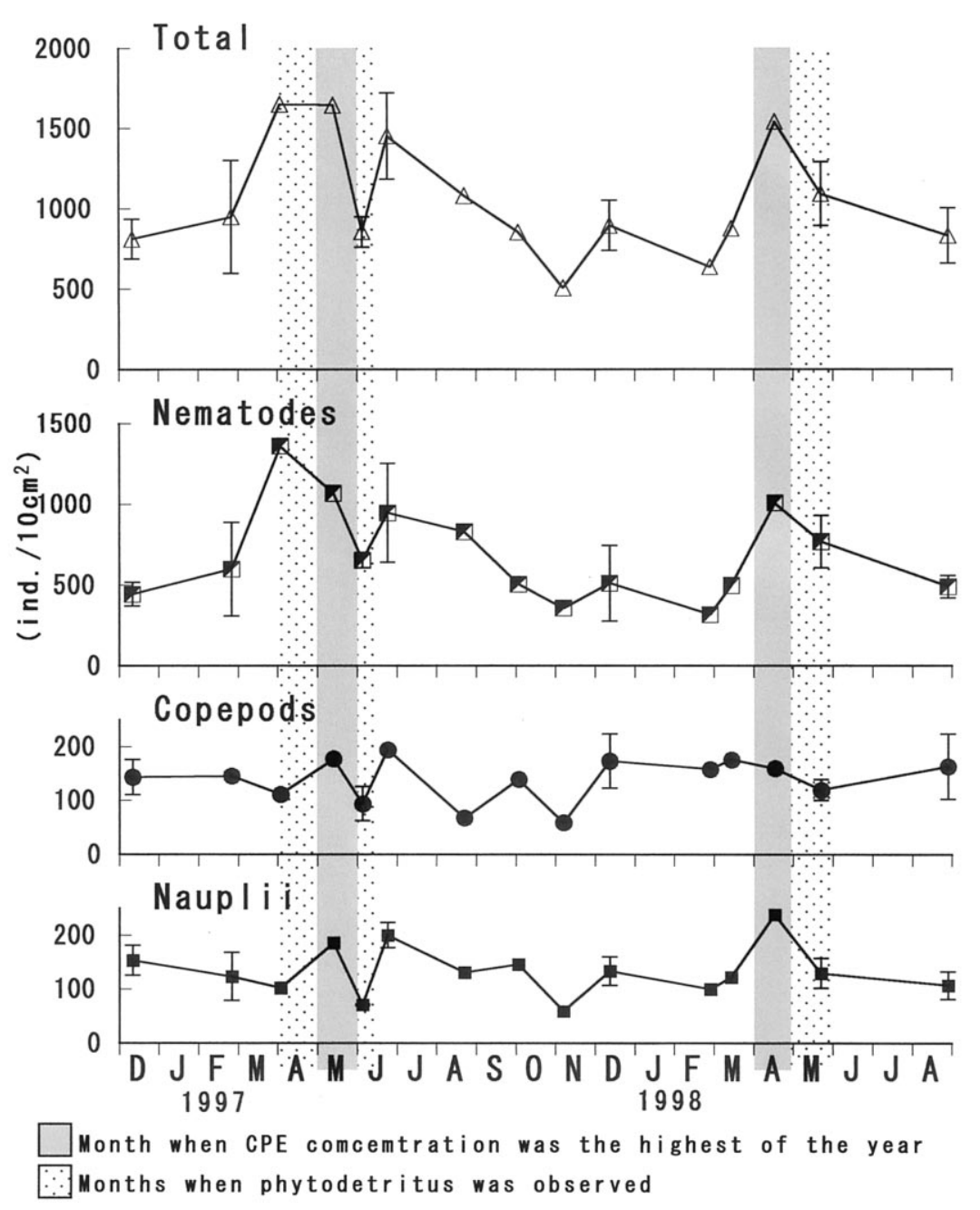

Figure 6. Seasonal change of integrated abundance of main meiofaunal groups in the top $5 \mathrm{~cm}$ sediment. Dots and bars denote the average and the standard deviation, respectively.

Table IV. The results of One-way ANOVA on meiofaunal abundance and biomass $(P \text { values })^{\mathrm{a}}$

\begin{tabular}{|c|c|c|c|c|c|c|c|c|}
\hline & \multicolumn{7}{|c|}{ Abundance } & \multirow{2}{*}{$\begin{array}{l}\text { Biomass } \\
\text { Total }\end{array}$} \\
\hline & Total & Nematodes & Copepods & Nauplii & Polychaetes & Kinorhynchs & Ostracods & \\
\hline $0-0.25 \mathrm{~cm}$ & 0.141 & 0.115 & 0.172 & 0.211 & 0.342 & 0.410 & 0.464 & 0.345 \\
\hline $0.25-0.50 \mathrm{~cm}$ & 0.54 & 0.106 & 0.079 & 0.020 & 0.242 & 0.070 & 0.122 & 0.066 \\
\hline $0.50-0.75 \mathrm{~cm}$ & 0.723 & 0.212 & 0.106 & 0.358 & 0.476 & 0.939 & 0.507 & 0.085 \\
\hline $0.75-1 \mathrm{~cm}$ & 0.177 & 0.135 & 0.174 & 0.030 & 0.675 & 0.641 & 0.275 & 0.130 \\
\hline $1-2 \mathrm{~cm}$ & 0.282 & 0.215 & 0.466 & 0.504 & 0.178 & 0.467 & 0.636 & 0.456 \\
\hline $2-3 \mathrm{~cm}$ & 0.253 & 0.39 & 0.124 & 0.221 & 0.667 & n.d. ${ }^{b}$ & n.d. & 0.065 \\
\hline $3-4 \mathrm{~cm}$ & 0.099 & 0.147 & 0.119 & 0.148 & 0.188 & n.d. & n.d. & 0.005 \\
\hline $4-5 \mathrm{~cm}$ & 0.267 & 0.388 & 0.390 & 0.311 & 0.379 & n.d. & n.d. & 0.135 \\
\hline $0-5 \mathrm{~cm}$ integrated & 0.202 & 0.092 & 0.083 & 0.017 & 0.851 & 0.152 & 0.225 & 0.156 \\
\hline
\end{tabular}

${ }^{\text {a }}$ Values bolded denote significant difference at alpha $=0.05$.

${ }^{\mathrm{b}}$ Not determined. 
The vertical distribution of CPE did not show a drastic decline with depth in the sediment. This result is different from observations made in the Porcupine Seabight and Goban Spur where CPE concentration decreased downward into the sediment $[32,35]$. In the Norwegian continental margin, Graf [19] suggested faecal pellets from the water column were incorporated in the sediment at a very rapid rate $(>1$ $\mathrm{cm} \cdot \mathrm{d}^{-1}$ ) due to the unidirectional transport of food particles into the burrow of the sipunculans Nephasoma sp. At our study site, tubes of polychaetes were very abundant $\left(1.9 \times 10^{2}-3.4 \times 10^{3}\right.$ tubes $/ \mathrm{m}^{2}$ in December 1997). The bioturbation activity of these polychaetes may play the same role as that of the sipunculans on the Norwegian continental margin.

\subsection{Benthic response to the sedimentation of organic matter}

Despite the decrease in the abundance of bacteria in winter, a clear seasonal pattern was not noticeable. Our result is different from the pattern at BIOTRANS site [28, 33, 34, 47] and off the bathyal Norwegian continental margin [19] where drastic sea-

Table V. SNK a posteriori test (min to max) on time series data of meiofauna ${ }^{a}$

\begin{tabular}{|c|c|c|c|c|c|c|c|}
\hline \multicolumn{8}{|c|}{ Abundance of Nauplii } \\
\hline $0.25-0.50 \mathrm{~cm}$ & $9706 \mathrm{a}$ & 9808 & 9712 & 9702 & 9805 & 9612 & $9706 \mathrm{~b}$ \\
\hline $0.75-1.0 \mathrm{~cm}$ & 9805 & $9706 \mathrm{a}$ & 9712 & $9706 \mathrm{~b}$ & 9808 & 9612 & 9702 \\
\hline $0-5 \mathrm{~cm}$ integrated & $9706 a$ & 9808 & 9702 & 9805 & 9712 & 9612 & $9706 b$ \\
\hline \multicolumn{8}{|c|}{ Median size of copepods } \\
\hline & $\underline{9805}$ & 9702 & $9706 \mathrm{~b}$ & 9712 & 9612 & 9808 & $9706 \mathrm{a}$ \\
\hline \multicolumn{8}{|c|}{ Biomass of total meiofauna } \\
\hline $3-4 \mathrm{~cm}$ & 9805 & 9702 & 9612 & 9712 & 9808 & $9706 \mathrm{~b}$ & $9706 \mathrm{a}$ \\
\hline
\end{tabular}

${ }^{a}$ Values from dates (first two figures, and the last figures denote year, and month respectively). With common underline are not significantly different. 9706a, 9706b denote earlier June in 1997 (KT-97-7), and later June in 1997 (KT-97-9), respectively.

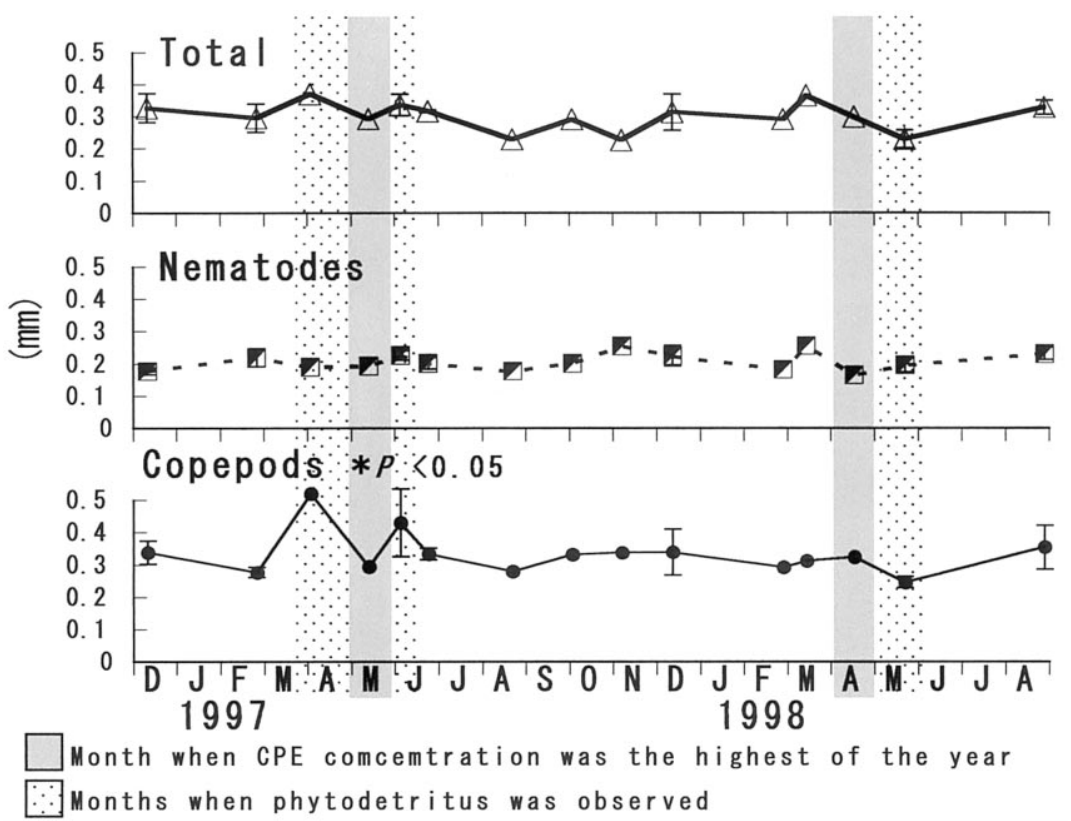

Figure 7. Seasonal change in median sizes of total meiofauna, nematodes, and copepods. 
sonal fluctuations of chlorophyll $a$ or CPE concentration in the sediment and clear response of benthic organisms to the sedimentation were observed. On the shelf and on the upper slope of the Goban Spur, the fluctuation of CPE values was moderate, namely those in May/June were 2-2.5 times higher than in April. In the case of SSCB (Small Size Class Biomass), the lowest figure in September was 30$50 \%$ lower than that in May/June [35]. In contrast to these sites, CPE values of our site were more stable as well as higher. This result suggests that the organicmatter necessary for the growth of bacteria is present constantly in the sediment of our site. Without the 'starvation period' in our site, the bacteria showed only a moderate change in abundance. The values of EC observed at our site were similar to those observed at other deep-sea sites [44]. Therefore, though bacteria are not starved, metabolic activity of benthic organisms was considered to remain low throughout the study period.

Although the correlation between the abundance of meiofauna and the concentration of chlorophyll $a$ and its derivatives in the deep-sea sediments is well known [3, 32, 36], much less is known about the dynamics of the meiofaunal communities. In particular, little is known about how they respond to the seasonally pulsed organic matter (phytodetritus) inputs. In sublittoral zones deeper than $30 \mathrm{~m}$, there seems to be no clear evidence that metazoan meiofaunal biomass and abundance increase follow sedimentation events [13, 22]. For example, at the abyssal BIOTRANS station in the NW Atlantic $\left(47^{\circ} \mathrm{N}\right.$, $20^{\circ}$ ? W, $4550 \mathrm{~m}$ depth), the abundance or biomass of the metazoan meio- and macrobenthos did not show seasonal change [34]. On the other hand, certain metazoan taxa, e.g. nematodes, harpacticoid copepods, and occasionally kinorhynchs, are known to respond to the input of phytodetritus [47]. In the NE Pacific $\left(34^{\circ} ? 50^{\prime} \mathrm{N}, 123^{\circ} ? 00^{\prime} \mathrm{W}, 4100 \mathrm{~m}\right.$ depth), Drazen et al. [10] also found that at an abyssal station, five dominant metazoan taxa (Nematoda, Polychaeta, Harpacticoida, Tanaidaca, and Isopoda) exhibited temporal increases in density after the disappearance of detrital aggregates from the sea bottom.

At our study site, the density of total metazoan meiofauna and some meiofaunal groups, especially nematodes, fluctuated in a similar pattern in both
1997 and 1998. Furthermore, the highest density was observed in the same periods as CPE concentration increased in the sediment (i.e. there was phytodetritus on the sediment). Statistical tests, however, did not confirm links between these two parameters. Although the statistically significant temporal fluctuation was found for nauplii, the duration of the fluctuation was much shorter than seasonal. Because nauplii are concentrated at the surface of the sediment (Shimanaga and Shirayama, unpublished data) in the present site, they are considered to be more susceptible to the disturbing event, such as benthic storms, like at the HEBBLE site [48].

In the present study, significant seasonal change was not found in any parameter of metazoan meiofauna at the higher taxonomic level. On the other hand, Ohga and Kitazato [31] found the shallow infaunal foraminiferans increased seasonally, and the deep infaunal species showed less pronounced seasonal fluctuations in population size at the same station. In the Porcupine Seabight, foraminiferal density increased after the delivery of a phytodetrital pulse to the seafloor $[16,17]$, but metazoan abundance and biomass did not [18]. Gooday et al. [18] considered that metazoans failed to exploit and utilize phytodetritus because they need more energy for egg production and their somatic growth is slower than foraminiferans. Complexities and differences in reproductive systems of metazoan species would be one of the reasons that total metazoan population did not change seasonally at our site.

The higher species diversity of metazoan meiofauna than foraminiferans is also noteworthy. In the case of foraminiferans, seven species were dominant and five of them declined in density in summer [25]. On the other hand, 21 species were found from 30 adult individuals of copepods (unpublished data), and it is unlikely that all these species will respond to the environmental change in the same manner.

Median sizes of total metazoan, nematodes, and copepods were constant throughout the years in Sagami Bay. These results are again different from those at BIOTRANS site, where the lengths and volumes of nematodes changed seasonally, corresponding to the trend of chlorophyll $a$ concentration [45]. An intrinsic life cycle might be present in deep- 
sea nematodes to adapt to the seasonally varying food availability at the latter site [45]. At the present site, on the other hand, temporal change of food supply was not sharp enough to intrinsically synchronize the reproductive cycle of nematodes to the food availability.

Fleeger and Shirley [12] found that the reproductive cycles in the dominant harpacticoid species in Auke Bay (Alaska) were related to the spring bloom sedimentation event, although densities of individual species were poorly related to the sedimentation. To understand the seasonality of deep-sea meiofauna, therefore, detailed information, e.g. population dynamics and life history at the individual species level, is necessary.

\section{Acknowledgements}

The authors are most grateful to T. Toyofuku, A. Yamaoka, M. Tsuchiya, S. Fujiwara, T. Kosugi, K. Seki, T. Okamoto, S. Koide, M. Suzuki M. Tazume, H. Nomaki, the officers and crew members of the R.V. Tansei-maru of Ocean Research Institute, and the R.V. Rinkai-maru of Misaki Marine Biological Station, University of Tokyo, for their help in the field research. They also thank H. Kitazato, T. Nakatsuka, M. Morisawa, Y. Kato, Y. Okada, J. Kanda, R.M. Ross, T. Masuzawa, K. Suzuki, S. Ohta, K. Aioi, S. Kojima, E. Tsuchida, H. Yeh, H. Urakawa, and M. Nakaoka for their help and discussions throughout the study. They thank two anonymous reviewers for their valuable suggestions. This study was partially supported by grant-in-aid 08304032, 06454008, and 08558061, from the ministry of education, science, culture and sports, Japan, and the research grant donated by the Mitsubishi Heavy Industry to YS.

\section{REFERENCES}

[1] Atkinson D.E., Adenine nucleotides as universal stoichiometric metabolic coupling agents, Adv. Enzyme Regul. 9 (1971) 207-219.

[2] Atkinson D.E., Walton G.M., Adenosine triphosphate conservation in metabolic regulation - rat liver cleavage enzyme, J. Biol. Chem. 242 (1967) 3239-3241.

[3] Alongi D.M., Pichon M., Bathyal meiobenthos of the western Coral Sea: distribution and abundance in relation to microbial standing stocks and environmental factors, Deep-Sea Res. 35 (1988) 491-503.

[4] Barnett P.R.O., Watson J., Conelly D., A multiple corer for taking virtually undisturbed samples from shelf, bathyal and abyssal sediments, Oceanol. Acta 7 (1984) 399-408.
[5] Beaulieu S.E., Smith K.L. Jr., Phytodetritus entering the benthic boundary layer and aggregated on the sea floor in the abyssal NE Pacific: macro- and microscopic composition, Deep-Sea. Res. II 45 (1998) 781-815.

[6] Billett D.S.M., Lampitt R.S., Rice A.L., Montoura R.F.C., Seasonal sedimentation of phytoplankton to the deep-sea benthos, Nature 302 (1983) 520-522.

[7] Bomsel J.L., Pradet A., Study of adenosine 5'-mono- di-, and triphosphates in plant tissues, IV. Regulation of the level of nucleotides, in vivo, by adenylate kinase; theoretical and experimental study, Biochim. Biophys. Acta 162 (1968) 230242.

[8] Corliss B., Silva K.A., Rapid growth of deep-sea benthic foraminifera, Geology (1993) 991-994.

[9] Deuser W.G., Ross E.H., Anderson R.F., Seasonality in the supply of sediment to the deep Sargasso Sea and implications for the rapid transfer of matter to the deep ocean, Deep-Sea Res. 28A (1981) 495-505.

[10] Drazen J.C., Baldwin R.J., Smith K.L. Jr., Sediment community response to a temporally varying food supply at an abyssal station in the NE pacific, Deep-Sea. Res. II 45 (1998) 893-913.

[11] Feller R.J., Warwick R.M., Energetics, in: Higgins R.P., Thiel H. (Eds.), Introduction to the study of Meiofauna, Smithsonian Institution Press, Washington, 1988, pp. 181-196.

[12] Fleeger J.W., Shirley T.C., Meiofaunal responses to sedimentation from an Alaskan spring bloom, II. Harpacticoid population dynamics, Mar. Ecol. Prog. Ser. 57 (1990) 239-247.

[13] Fleeger J.W., Shirley T.C., Ziemann D.A., Meiofaunal responses to sedimentation from an Alaskan spring bloom, I. Major taxa, Mar. Ecol. Prog. Ser. 59 (1989) 137-145.

[14] Gooday A.J., A response by benthic Foraminifera to the deposition of phytodetritus in the deep sea, Nature 332 (1988) $70-73$.

[15] Gooday A.J., Xenophyopohores (Protista, Rhizopoa) in boxcore samples from the abyssal northeast Atlantic ocean (BIOTRANS area): their taxonomy, morphology, and ecology, J. Foram. Res. 21 (1991) 197-212.

[16] Gooday A.J., Lambshead P.J.D., Influence of seasonally deposited phytodetritus on benthic foraminiferal populations in the bathyal northeast Atlantic: the species reponse, Mar. Ecol. Prog. Ser. 58 (1989) 53-67.

[17] Gooday A.J., Turley C.M., Responses by benthic organisms to inputs of organic material to the ocean floor: a review, Philos. Trans. Roy. Soc. Lond. A 331 (1990) 119-138.

[18] Gooday A.J, Pfannkuche O., Lambshead P.J.D., An apparent lack of response by metazoan meiofauna to phytodetritus decomposition on the bathyal north-eastern Atlantic, J. Mar. Biol. Ass. UK 76 (1996) 297-310.

[19] Graf G., Benthic-pelagic coupling in a deep-sea benthic community, Nature 341 (1989) 437-439.

[20] Greiser N., Faubel A., Biotic Factors, in: Higgins R.P., Thiel H. (Eds.), Introduction to the study of Meiofauna, Smithsonian Institution Press, Washington, 1988, pp. 79-114. 
[21] Hecker B., Photographic evidence for the rapid of particles to the sea floor and their transport down the continental slope, Deep-Sea Res. 37 (1990) 1773-1782.

[22] Heip C., Vincx M., Vranken G., The ecology of marine nematodes, Oceanogr. Mar. Biol. Ann. Rev. 23 (1985) 399489.

[23] Holm-Hansen O., Lorenzen C.J., Holmes C.R.W., Strickland J.D.H., Fluorometric determination of chlorophyll, J. Cons. Perm. Int. Explor. Mer. 30 (1965) 3-15.

[24] Honjo S., Seasonality and interaction of biogenic and lithogenic particulate flux at the Panama Basin, Science 218 (1982) $883-884$

[25] Kitazato H., Ohga T., Seasonal changes in deep-sea benthic foraminiferal populations: results of long-term observations at Sagami Bay, Japan, in: Sakai H., Nozaki Y. (Eds.), Biogeochemical Processes and Ocean Flux in the Western Pacific, Terra Scientific Publishing Co., Tokyo, 1995, pp. $331-342$.

[26] Kitazato H., Nakatsuka T., Fujiwara S., Shimanaga M., Kato Y., Okada Y., Kanda J., Yamaoka A., Masuzawa T., Suzuki K., Shirayama Y., Carbon cycling in a eutrophic marginal sea - Time series observations at Sagami Bay, In Land-Sea Link in Asia, "Prof. Kenneth O. Emery Commemorative International Workshop", Proceedings of an international workshop on sediment transport and storage in coastal sea-ocean system, 1999 , pp. $372-377$.

[27] Lampitt R.S., Evidence for the seasonal deposition of detritus to the deep-sea floor and its subsequent resuspension, DeepSea Res. 32 (1985) 885-897.

[28] Lochte K., Bacterial standing stock and consumption of organic carbon in the benthic boundary layer if the abyssal north Atlantic, in: Rowe G.T., Pariente V. (Eds.), Deep-sea food chains and the global carbon cycle, Kluwer Academic Publishers, Amsterdam, 1992, pp. 1-10.

[29] Lochte K., Turley C.M., Bacteria and cyanobacteria associated with phytodetritus in the deep sea, Nature 333 (1988) $67-69$.

[30] Noriki S., Shimizu M., Hamahara K., Narita H., Saino T., Yanagi T., Transportation of particulate material through the mouth of Tokyo Bay to the open ocean, J. Oceanogr. 53 (1997) 571-577.

[31] Ohga T., Kitazato H., Seasonal changes in bathyal foraminiferal populations in response to the flux of organic matter (Sagami Bay, Japan), Terra Nova 9 (1997) $33-37$.

[32] Pfannkuche O., The deep-sea meiofauna of the Porcupine Seabight and abyssal plain (NE Atlantic): population structure, distribution, standing stocks, Oceanol. Acta 8 (1985) $343-353$.

[33] Pfannkuche O., Organic carbon flux through the benthic community in the temperate abyssal northeast Atlantic, in: Rowe G.T., Pariente V. (Eds.), Deep-sea food chains and the global carbon cycle, Kluwer Academic Publishers, Amsterdam, 1992, pp. 183-198.
[34] Pfannkuche O., Benthic response to the sedimentation of particulate organic matter at the BIOTRANS station, $47 \mathrm{~N}$, 20 W, Deep-Sea. Res. II 40 (1993) 135-149.

[35] Pfannkuche O., Soltwedel T., Small benthic size classes along the NW European Continental Margin: spatial and temporal variability in activity and biomass, Prog. Oceanogr. 42 (1998) 189-207.

[36] Pfannkuche O., Thiel H., Meiobenthic stocks and benthic activity on the NE-Svalbard Shelf and in the Nansen Basin, Polar Biol. 7 (1987) 253-266.

[37] Pfannkuche O., Boetius A., Lochte K., Lundgreen U., Thiel H., Responses of deep-sea benthos to sedimentation patterns in the NE Atlantic in 1992, Deep-Sea Res. I 46 (1999) $573-596$.

[38] Porter K.G., Feig Y.S., The use of DAPI for identifying and counting aquatic microflora, Limnol. Oceanogr. 25 (1980) 943-948.

[39] Rice A.L., Billet D.S.M., Fry J., John A.W.G., Lampitt R.S., Mantoura R.F.C., Morris R.J., Seasonal deposition of phytodetritus to the deep-sea floor, Proc. Roy. Soc. Edinburgh 88B (1986) 265-279.

[40] Riemann F., Gelatinous phytoplankton detritus aggregations on the Atlantic deep-sea bed, Structure and mode of formation, Mar. Biol. 100 (1989) 533-539.

[41] Shirayama Y., Size structure of deep-sea meio- macrobenthos in the western Pacific, Int. Rev. ges. Hydrobiol. 68 (1983) 799-810.

[42] Smith C.R., Tempo and Mode in Deep-sea benthic ecology: Punctuated Equilibrium Revisited, Palaios 9 (1994) 3-13.

[43] Smith K.L. Jr., Kaufmann R.S., Baldwin R.J., Coupling of near-bottom pelagic and benthic processes at abyssal depths in the eastern North Pacific Ocean, Limnol. Oceanogr. 39 (1994) $1101-1118$

[44] Soltwedel, Thiel H., Biogenic sediment compounds in relation to marine meiofaunal abundances, Int. Rev. ges. Hydrobiol. 80 (1995) 297-311.

[45] Soltwedel, Pfannkuche O., Thiel H., The size structure of deep-sea meiobenthos in the northeastern Atlantic: nematode size spectra in relation to environmental variables, J. Mar. Biol. Ass. UK 76 (1996) 327-344.

[46] Takahasi K., Seasonal fluxes of pelagic diatoms in the subarctic Pacific, 1982-1983, Deep-Sea Res. 33 (1986) 1225-1251.

[47] Thiel H., Pfannkuche O., Schriever G., Lochte K., Gooday A.J., Hemleben C.H., Mantoura R.F.G., Turley C.M., Patching J.W., Riemann F., Phytodetritus on the Deep-Sea floor in a Central Oceanic region of the northeast Atlantic, Biol. Oceanogr. 6 (1988-1989) 203-239.

[48] Thistle D., A temporal difference in harpacticoid-copepod abundance at a deep-sea site: caused by benthic storms ?, Deep-Sea Res. 35 (1988) 1015-1020.

[49] Turley C.M., Lochte K., Patterson D.J., A barophilic flagellate isolated from $4500 \mathrm{~m}$ in the mid-North Atlantic, DeepSea Res. 35 (1988) 1079-1092. 
[50] Turley G.M., Lochte K., Lampitt R.S., Transformations of biogenic particles during sedimentation in the northeastern Atlantic, Philos. Trans. Roy. Soc. B 348 (1995) 179-189.

[51] van Weering T.C.E., McCave I.N., Hall I.R., Ocean margin exchange (OMEXI) benthic processes study, Prog. Oceanogra. 42 (1998) $1-4$.
[52] Yentsch C.S., Menzel D.W., A method for the determination of phytoplankton chlorophyll and phaeophytin by fluorescence, Deep-Sea Res. 10 (1963) 221-231.

[53] Zar J.H., Biostatistical Analysis, Fourth edition, PrenticeHall, N.J., 1999, p. 663 